\title{
Factors Affecting Application of Milk Allantoin as an Estimator of Microbial Protein Flow to the Duodenum Under Commercial Conditions
}

\author{
W. M. Schager, ${ }^{*}$ J. H. Harrison,† C. T. Gaskins, ${ }^{*}$ and D. Davidson† \\ *Department of Animal Sciences, Washington State University, Pullman 99164 \\ †Washington State University, Puyallup 98371
}

\section{ABSTRACT}

Three experiments were conducted to determine the effect of diet change, milk sampling technique, and bovine somatotropin (bST) on allantoin output in milk and the use of allantoin as a practical, noninvasive method for estimating microbial protein flow in dairy cattle. In experiment 1 , four lactating Holstein cows were used in a $2 \times 2$ Latin square design with two treatments (ratio of forage to concentrate) and two periods. In experiment 2, six Holstein cows were used in a completely randomized design, and milk was collected by 1) a strip sample collected immediately before milking, 2) a strip sample collected 3 min from start of milking, and 3) a composite sample taken with an autosampler. In experiment three, 10 cows were used in a randomized block design to determine the effect of bST on milk allantoin. Milk samples were taken daily for $21 \mathrm{~d}, 7 \mathrm{~d}$ before, and $14 \mathrm{~d}$ after bST administration. In experiment 1 , allantoin output ( $\mathrm{mmol} / \mathrm{d}$ ) was significantly greater for cows fed the higher ratio of concentrate to forage, and there was a significant change in the amount of allantoin in milk $12 \mathrm{~h}$ (first subsequent milking) after a diet change. There was no difference in milk yield or dry matter intake between treatments. In experiment 2, no difference was detected in milk allantoin concentration among the three sampling methods. In experiment 3 , milk yield, allantoin concentration, and total allantoin output was significantly increased after bST administration even though dry matter intake (DMI) remained unchanged. During the first $14 \mathrm{~d}$ following bST administration, estimates of microbial protein production derived from milk allantoin may be inaccurate due to increased milk production without an increase in DMI.

(Key words: milk, allantoin, microbial protein)

Received July 3, 2002.

Accepted October 18, 2002.

Corresponding author: J.H. Harrison; e-mail: harrison@puyallup. wsu.edu.

\section{INTRODUCTION}

The ability to accurately measure microbial protein supply is of prime importance in dairy nutrition. Previous work characterizing protein synthesis by the rumen microbial population has required surgical cannulation of the rumen and duodenum. However, cannulation is costly, increases animal care concerns, and can lower DMI and milk production (Wenham, 1979). This has led to the development of noninvasive techniques to measure microbial protein synthesis.

Topps and Elliott (1965) first proposed the use of urinary purine derivatives as a metabolic marker of microbial synthesis in ruminants, whereas more recent studies have worked towards establishing methods relating purine derivative excretion to microbial yield (Stangassinger et al., 1995). This method assumes that nucleic acids entering the duodenum are all of microbial origin. Purine nucleotides are degraded in the intestine and absorbed. Adenine and guanine are catabolized and excreted via four possible routes: renal, mammary gland, recycling via saliva (Sibanda et al., 1982; Chen et al., 1990), and secretion into the intestines (Chen, 1989). The purine derivatives are excreted primarily as allantoin but also as hypoxanthine, xanthine, and uric acid (Chen, 1989). Allantoin and uric acid are the only purine derivatives excreted by cattle due to high xanthine oxidase activity in the blood and tissues, which converts xanthine and hypoxanthine into uric acid prior to excretion (Chen and Gomes, 1992).

Use of milk allantoin excretion to estimate microbial protein flow to the duodenum has been evaluated in several studies (Gonda and Lindberg, 1997; Shingfield and Offer, 1998; Valadares et al., 1999; Timmermans et al., 2000). There is a positive relationship between milk allantoin excretion and microbial nitrogen flow in dairy cattle fed a wide range of diets and with different physiological states (Timmermans et al., 2000). However, temporal response, sample collection method, and bST use are three factors that could affect the accuracy of prediction of microbial protein flow. Timmermans et al. (2000) observed an effect of bST on allantoin output in milk, but the experimental design did not allow for 
Table 1. Ingredient composition of lactation diet in experiment 1.

\begin{tabular}{lll}
\hline & \multicolumn{2}{c}{ Diet, ${ }^{1} \%$ of DM } \\
\cline { 2 - 3 } Ingredient & $40: 60$ & $60: 40$ \\
\hline Corn silage & 27.3 & 20.5 \\
Alfalfa hay & 13.6 & 39.5 \\
Whole cottonseed & 13.6 & 13.6 \\
Grain mix $^{2}$ & 45.5 & 26.4 \\
\hline
\end{tabular}

${ }^{1} 40: 60=40 \%$ forage, $60 \%$ concentrate; $60: 40=60 \%$ forage, $40 \%$ concentrate.

${ }^{2}$ Grain mix: $27.4 \%$ barley (50\% rolled:50\% ground), $27.4 \%$ corn $(50 \%$ rolled:50\% ground), $11.0 \%$ soybean meal, $9.0 \%$ wheat mill run, $5.1 \%$ beet pulp, 7.3\% Prolak (menhaden fishmeal, blood meal, porcine meat and bone meal, hydrolyzed feather meal, and Mepron - H. J. Baker \& Bros., Inc., Atlanta, GA), $4.0 \%$ sodium bicarbonate, $1.8 \%$ molasses, $1.8 \%$ limestone, $0.88 \%$ Biophos (ADM, Des Moines, IA) 0.39\% magnesium oxide, $0.10 \%$ lactating premix ( $5875 \mathrm{IU} / \mathrm{g}$ vitamin A, $2646 \mathrm{IU} /$ $\mathrm{g}$ vitamin D, $14 \mathrm{IU} / \mathrm{g}$ vitamin E, $220 \mathrm{mg} / \mathrm{kg} \mathrm{Co}, 16,500 \mathrm{mg} / \mathrm{kg} \mathrm{Cu}, 660$ $\mathrm{mg} / \mathrm{kg} \mathrm{Fe}, 44,000 \mathrm{mg} / \mathrm{kg} \mathrm{Mn}, 44,000 \mathrm{mg} / \mathrm{kg} \mathrm{Zn}, 880 \mathrm{mg} / \mathrm{kg} \mathrm{I}, 220 \mathrm{mg} /$ $\mathrm{kg} \mathrm{Se}) 2.5 \%$ blood meal, $0.10 \%$ vitamin E premix (44 IU/g), $0.01 \%$ vitamin A premix (30,000 IU/g), 0.12\% selenium premix $(220 \mathrm{mg} / \mathrm{kg})$, $0.29 \%$ Alimet (Novus Int., Inc., St. Louis, MO), 0.49\% lysine $\mathrm{HCl}$, $0.44 \%$ salt (iodized).

identification of the bST association. We think that factors unrelated to diet (diet composition or DMI) that increase milk production could possibly affect the predictability of microbial nitrogen flow from milk allantoin output. Use of milk allantoin as an estimator for microbial nitrogen flow on commercial dairies will require greater understanding of the effect of these factors.

The objectives of these studies were to determine the effect of 1) diet change on the temporal change in milk allantoin output, 2) milk sample collection techniques for allantoin determinations, and 3) bST administration on milk allantoin concentration and output.

\section{MATERIALS AND METHODS}

\section{General}

Three experiments were conducted using lactating Holstein cows. Experiment 1 was conducted at the Washington State Dairy Forage Facility in Buckley, WA. Experiments 2 and 3 were conducted at the Washington State University Knott Dairy Center in Pullman, WA. Experiments were approved by the Washington State University Institutional Animal Care and Use Committee.

Experiment 1. In experiment 1, four multiparous, lactating Holstein cows were used in a $2 \times 2$ Latin square design to determine the effect of a dietary change in the ratio of forage to concentrate on the temporal change of allantoin output in milk. There were two experimental periods consisting of $5 \mathrm{~d}$ each. Treatments included two diets, fed as a TMR, differing in the ratio
Table 2. Chemical composition of total mixed rations in experiment 1.

\begin{tabular}{lcc}
\hline & \multicolumn{2}{c}{ Ration, \% of $\mathrm{DM}^{1}$} \\
\cline { 2 - 3 } & $40: 60$ & $60: 40$ \\
\hline $\mathrm{CP}, \%$ & 18.4 & 19.0 \\
NDF, \% & 39.2 & 45.7 \\
ADF, \% & 28.0 & 35.5 \\
Ether extract, \% & 5.27 & 3.36 \\
Ca, \% & 1.03 & 1.24 \\
P,\% & 0.54 & 0.51 \\
K, \% & 1.39 & 2.05 \\
Na, \% & 0.89 & 0.73 \\
Zn, mg/kg & 136 & 96 \\
\hline
\end{tabular}

${ }^{1} 40: 60=40 \%$ forage, $60 \%$ concentrate; $60: 40=60 \%$ forage, $40 \%$ concentrate.

of forage to concentrate (40:60 and 60:40). Diet and chemical composition of the diets are described in Tables 1 and 2, respectively. Cows were individually fed using Calan headgates (American Calan, Inc., Northwood, $\mathrm{NH}$ ) in a free-stall barn, and daily feed intakes measured. Samples of the TMR were obtained once per period and sent for analysis for DM, CP, ether extract, $\mathrm{ADF}$, and NDF (Dairyland Laboratories, Inc., Arcadia, WI).

Milk samples from the a.m. (0630 h) and p.m. (1830 h) milkings were collected for the duration of the experiment and immediately frozen $\left(-20^{\circ} \mathrm{C}\right)$ for later analysis of allantoin. Additional milk samples were collected from the last three milkings of each period and analyzed by the regional DHIA laboratory (Burlington, WA) for fat, protein, lactose, solids nonfat, and SCC using infared spectrophotometry (Bently 2000; Bently Instruments, Chaska, MN). Milk weights were recorded for each milking.

Experiment 2. In experiment 2, six multiparous, lactating Holstein cows were assigned to three treatments in a completely randomized design to determine the effect of milk sampling technique on milk allantoin concentration. Treatments were 1) strip sample taken immediately before milking, 2) strip sample collected 3 min from start of milking, and 3) a composite sample taken with an autosampler (Bou-Matic, Madison, WI). Cows were sampled during one a.m. milking (1030 h). Milking time and milk yield were recorded for each cow. Milk samples were frozen $\left(-20^{\circ} \mathrm{C}\right)$ for later allantoin analysis.

Experiment 3. In experiment 3, 10 lactating cows (two primiparous and eight multiparous) were used in a randomized complete block design in order to determine the effect of bST on milk allantoin. This experiment was conducted in conjunction with a feeding trial designed to determine the effect of dietary cobalt supplementation on metabolism and performance of dairy 
Table 3. Least squares means of feed intake, milk allantoin, milk yield, milk fat, and protein percentages for cows fed different lactation diets in experiment $1 .^{1}$

\begin{tabular}{|c|c|c|c|c|}
\hline \multirow[b]{2}{*}{ Measure } & \multicolumn{2}{|c|}{ Treatment $^{2}$} & \multirow[b]{2}{*}{$\mathrm{SE}$} & \multirow[b]{2}{*}{$P<$} \\
\hline & $40: 60$ & $60: 40$ & & \\
\hline DMI (kg/d) & 24.4 & 24.6 & 0.86 & 0.88 \\
\hline Milk allantoin $(\mathrm{mmol} / \mathrm{d})$ & 15.7 & 12.5 & 0.41 & 0.03 \\
\hline Milk yield (kg/d) & 38.7 & 34.8 & 0.84 & 0.08 \\
\hline Milk fat (\%) & 3.54 & 3.36 & 0.22 & 0.63 \\
\hline Milk protein (\%) & 3.02 & 2.97 & 0.02 & 0.29 \\
\hline
\end{tabular}

${ }^{1}$ Means given represent last $2 \mathrm{~d}$ of each period.

${ }^{2} 40: 60=40 \%$ forage, $60 \%$ concentrate; $60: 40=60 \%$ forage, $40 \%$ concentrate.

cows. Five cows were used for milk collections for $14 \mathrm{~d}$ (7 d pre- and $7 \mathrm{~d}$ post-bST administration), while milk of the other five cows was collected for $21 \mathrm{~d}$ ( $7 \mathrm{~d}$ preand $14 \mathrm{~d}$ post-bST administration). Milk samples were taken daily at $1200 \mathrm{~h}$ during the a.m. milking for the entire period and frozen $\left(-20^{\circ} \mathrm{C}\right)$ for later analysis. Beginning at 90 DIM, all cows received bST injections biweekly. Not all cows started the trial on the same calendar day. Animals were individually fed a TMR (Table 4) using Calan headgates (American Calan, Inc., Northwood, NH), and daily feed intakes measured.

Table 4. Ingredient composition of total mixed rations in experiment 3 .

\begin{tabular}{lc}
\hline Ingredient & $\%$, DM basis \\
\hline Alfalfa silage & 27.08 \\
Alfalfa hay & 23.70 \\
Wheat mill run & 6.94 \\
Cottonseed, whole & 10.38 \\
Concentrate & \\
Corn, ground & 84.18 \\
Peas, ground & 7.89 \\
Soybean meal (48\% protein) & 2.63 \\
Molasses & 2.5 \\
Limestone & 1.58 \\
Sodium bicarbonate & 1.5 \\
Salt & 0.50 \\
TM salt ${ }^{1}$ & 0.50 \\
Animal fat & 0.50 \\
Magnesium oxide & 0.40 \\
Vitamin A premix & \\
Vitamin D premix & \\
Se premix & 0.025 \\
Cellulose gum & 0.05 \\
Concentrate in TMR & 0.20 \\
Total & 0.05 \\
\hline
\end{tabular}

${ }^{1}$ The TM salt premixes contained $0,1.55$, and $3.10 \%$ cobalt glucoheptonate. Other ingredients were $1.3 \% \mathrm{Cu}$ sulfate, $3.24 \% \mathrm{Cu}$ lysine, $1.41 \% \mathrm{Mn}$ oxide, $6.47 \% \mathrm{Mn}$ methionine, $9.4 \% \mathrm{Zn}$ methionine (ZnPro$100), 4.56 \% \mathrm{Zn}$ sulfate, and the remainder $(70.52$ to $73.62 \%)$ was iodized salt.

${ }^{2}$ Contained 30,000 IU of vitamin A/g of premix.

${ }^{3}$ Contained 8810 IU of vitamin D/g of premix.

${ }^{4}$ Contained $0.02 \%$ Se as sodium selenate.
Table 5. Chemical composition of total mixed rations in experiment 3.

\begin{tabular}{ll}
\hline & Ration, \% of DM \\
\hline CP, \% & 18.1 \\
NDF, \% & 35.3 \\
ADF, \% & 21.7 \\
Ether extract, \% & 4.4 \\
Ca, \% & 0.68 \\
P, \% & 0.37 \\
K, \% & 1.02 \\
Na, \% & 0.16 \\
\hline
\end{tabular}

Composite feed samples were dried $\left(60^{\circ} \mathrm{C}\right.$ for $\left.48 \mathrm{~h}\right)$, ground to pass a 2-mm screen (Wiley mill; Arthur H. Thomas Co., Philadelphia, PA), subsampled, then reground to pass through a $1-\mathrm{mm}$ screen, subsampled again, and stored at $-30^{\circ} \mathrm{C}$ until further analysis. Feed analysis consisted of $\mathrm{DM}$ at $60^{\circ} \mathrm{C}(\mathrm{AOAC}, 1990)$, crude protein, and ether extract (AOAC, 1990), and NDF and ADF according to Goering and Van Soest (1970) with addition of amylase. The chemical composition of the TMR is given in Table 5. All three diets fed in the cobalt trial held in conjunction with this trial were similar except for amount of cobalt $(0.37,0.68$, and $1.26 \mathrm{mg} / \mathrm{kg})$.

\section{Milk Sample Preparation and Analysis}

Milk samples were thawed and centrifuged at 1000 $\times g$ for 15 min at $4^{\circ} \mathrm{C}$ to remove fat. Milk protein was precipitated with a 1:1 dilution of the lower phase with $3 \%$ TCA and centrifuged $\left(1000 \times g\right.$ for $15 \mathrm{~min}$ at $\left.4^{\circ} \mathrm{C}\right)$. Milk was analyzed for allantoin in all experiments according to the procedure described by Chen (1989) and for uric acid (Sigma Diagnostics, St. Louis, MO) in experiment 3. Total excretion of allantoin was computed as the product of the milk volume obtained during each period (milking or day) and allantoin concentration.

\section{Statistical Analysis}

The GLM procedure of SAS (V8.0, SAS Institute, Inc., Cary, NC) was used for conducting all statistical analyses. Statistical significance was declared at $P<0.05$ and a trend was declared at $P<0.10$.

Experiment 1. In experiment 1, effect of diet was analyzed in a $2 \times 2$ Latin square replicated twice. The model was $\mathrm{Y}_{\mathrm{ijk}}=\mu+\operatorname{diet}_{\mathrm{i}}+$ period $_{\mathrm{j}}+$ square $_{\mathrm{k}}+$ cow (square $)_{\mathrm{kl}}+\mathrm{e}_{\mathrm{ijkl}}$ where $\mathrm{Y}_{\mathrm{ijk}}=$ dependent variable, $\mu=$ overall mean, diet $_{\mathrm{i}}=$ effect of diet $(\mathrm{i}=1,2)$, period $_{\mathrm{j}}=$ effect of period $(\mathrm{j}=1,2)$, square $_{\mathrm{k}}=$ effect of square $(\mathrm{k}$ $=1,2), \operatorname{cow}(\text { square })_{\mathrm{kl}}=$ effect of cow within square $(\mathrm{l}=$ $1,2,3,4)$, and $\mathrm{e}_{\mathrm{ijkl}}$ is the residual. Cow(square) ${ }_{\mathrm{kl}}$ was used as the error term for testing diet and period.

Experiment 2. In experiment 2, effect of sampling method was analyzed in a completely randomized de- 
sign with the model: $\mathrm{Y}_{\mathrm{ij}}=\mu+$ sampling $\operatorname{method}_{\mathrm{i}}+\mathrm{e}_{\mathrm{ij}}$ where $\mathrm{Y}_{\mathrm{ij}}=$ dependent variable, $\mu$ = overall mean, sampling $\operatorname{method}_{i}=$ effect of sampling method $(i=1,2,3)$, and $\mathrm{e}_{\mathrm{ij}}=$ error.

Experiment 3. In experiment 3, effects of days were analyzed in a randomized block design with cows as blocks. The model was $\mathrm{Y}_{\mathrm{ij}}=\operatorname{cow}_{\mathrm{i}}+\operatorname{day}_{\mathrm{j}}+\mathrm{e}_{\mathrm{ij}}$ where $\mathrm{Y}_{\mathrm{ij}}$. = dependent variable, $\operatorname{cow}_{\mathrm{i}}=$ effect of cow $(\mathrm{i}=1,2, \ldots$, $10)$, day $_{j}=$ effect of day $(j=1,2, \ldots, 21)$, and $e_{i j}=$ error. Preplanned contrasts were computed and tested using the ESTIMATE function of the GLM procedure to determine the impact of bST administration. The slope over d 1 through 7 was tested against the slope over d 8 through 14. Further, the slope of $d 1$ through 7 and for d 8 through 14 were each tested separately for the difference from 0 .

\section{RESULTS AND DISCUSSION}

\section{Experiment 1}

There was no difference in DM intakes between the two treatments (Table 3). Likewise, no difference was observed in milk fat or milk protein percentage between treatments. There was a trend $(P<0.08)$ in milk production to be greater when cows were fed the diet with increased concentrate and milk allantoin output ( $\mathrm{mmol} /$ d) was greater $(P<0.03)$ when cows were fed the diet with increased concentrate (Table 3). High correlations have been found between allantoin output and milk yield (Giesecke et al., 1994; Timmermans et al., 2000). Gonda and Lindberg (1997) also reported increased concentration and secretion of allantoin in milk as DMI and the amount of concentrate in the diet increased. Valadares et al. (1999) fed diets of different concentrate percentage $(20,35,50$, and $65 \%)$ to multiparous Holstein cows and found secretion of allantoin in milk increased with increased dietary concentrate percent (18.7 to $28.6 \mathrm{mmol} / \mathrm{d}, \mathrm{SE}=0.5$; low concentrate and high concentrate diets, respectively).

The increase $(P<0.02)$ in milk allantoin excretion after the diet change was rapid and occurred within 12 $\mathrm{h}$ (first subsequent milking) after a change in the diet (Figure 1). Based on these observations, a detection of milk allantoin was evident, because it changed quickly before there was a change in milk production due to the increased concentrate in the diet.

\section{Experiment 2}

Allantoin concentrations between the three milk sample collection methods were 83.0, 86.0, and 83.8 $\mathrm{mg} / \mathrm{L}$ (pre, mid, and composite, respectively; $\mathrm{SE}=3.08$ ) and were not different. The average milk production for all cows was $21.8 \mathrm{~kg}(\mathrm{SE}=2.04)$, whereas the average

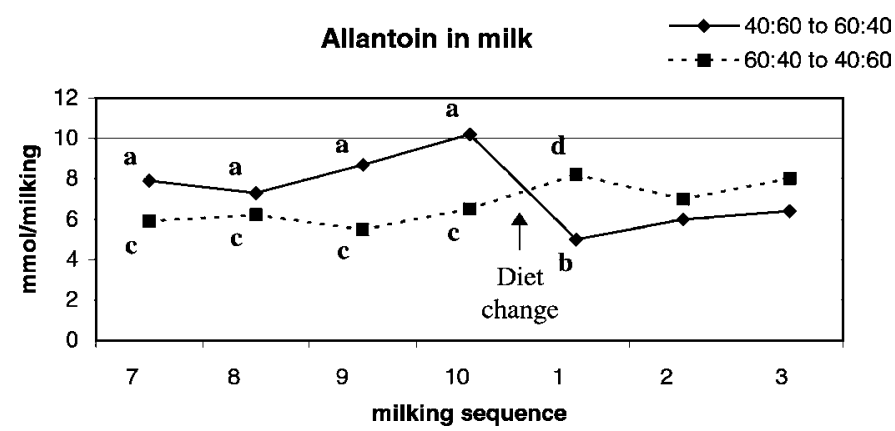

Figure 1. Temporal changes in milk allantoin amount in experiment $1 .{ }^{1}$ Legend: 40:60 to 60:40 = first fed $40 \%$ forage, $60 \%$ concentrate ration, then switched to $60 \%$ forage, $40 \%$ concentrate; $60: 40$ to $40: 60$ $=$ first fed $60 \%$ forage, $40 \%$ concentrate ration, then switched to $40 \%$ forage, $60 \%$ concentrate ration. ${ }^{a, b, c, d}$ Means within same diet with different superscripts differ $(P<0.02)$.

milking time was $8.2 \mathrm{~min}(\mathrm{SE}=0.65)$. It is unclear from previous work if milk samples were obtained via strip or composite sampling techniques. Although composite sampling with the aid of a mechanical collection device is common on dairy farms, some dairies may not have this option and instead, obtain a milk sample via the strip technique. From our results, this would be a viable alternative.

\section{Experiment 3}

When comparing the contrasts of the slopes of $\mathrm{d} 1$ to 7 vs. the slope of d 8 to 14, there was no effect of bST on DMI of cows for the $21 \mathrm{~d}$ of the study. Bauman et al. (1985) gave bST to Holstein cows beginning in the third month of lactation and found energy intake remained relatively constant for approximately 5 wk after the start of injections. More recent studies have also reported no increase in DMI for several weeks after bST injection (Chalupa and Galligan, 1989; Bauman, 1992). However milk yield did increase $(P<0.0001)$ after administration of bST. In general, milk yield will gradually increase over the first few days of bST treatment and reach a maximum during the first week (Etherton and Bauman, 1998).

Allantoin concentration $(\mathrm{mg} / \mathrm{L})$ and the total amount of allantoin secreted $(\mathrm{mmol} / \mathrm{d})$ in milk are shown in Figures 2 and 3. Administration of bST increased $(P<$ $0.0001)$ total allantoin secreted $(\mathrm{mmol} / \mathrm{d})$ in milk and allantoin concentration $(\mathrm{mg} / \mathrm{L})(P<0.0006)$.

Timmermans et al. (2000) showed a positive relationship between microbial nitrogen flow and allantoin excretion in milk over a wide range of diets and physiological states. The regression equation derived by Timmermans et al. (2000) includes DMI as one of the variables considered. With no increase in DMI, an increase in 

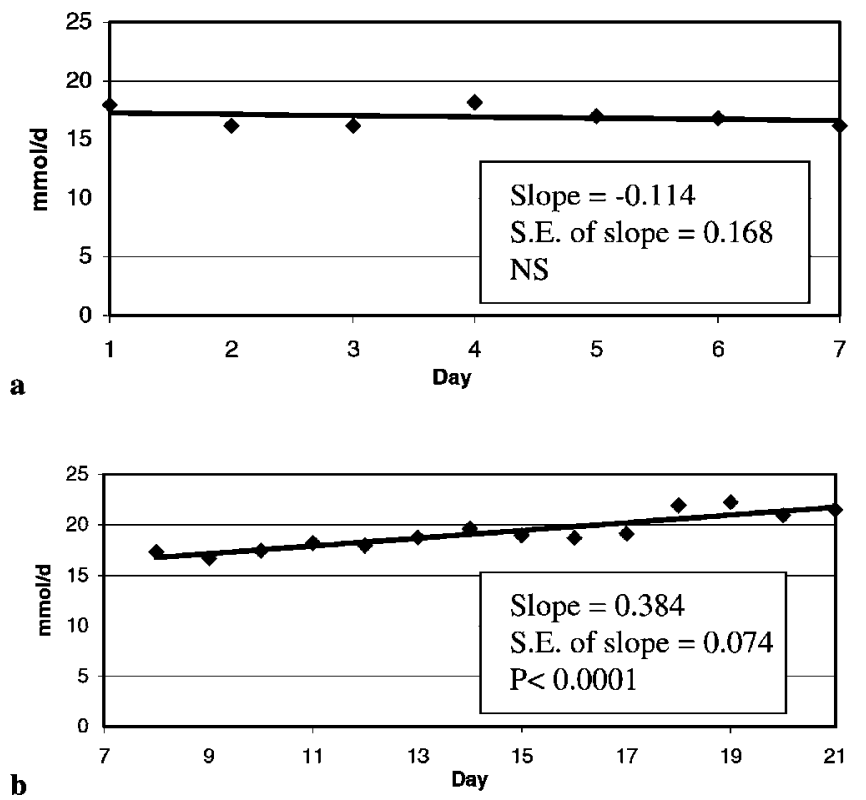

Figure 2. Amount of allantoin excreted per day over the course of experiment 3. a) Allantoin excretion before administration of bST (d 1 to 7), b) Allantoin excretion after administration of bST (d 8 to 21).

microbial nitrogen flow would not be expected. Allantoin secreted in milk is assumed to be derived from plasma as a result of diffusion into mammary alveolar cells (Tiermeyer et al., 1984, Geisecke et al., 1994). Furthermore, allantoin fluxes entering the mammary
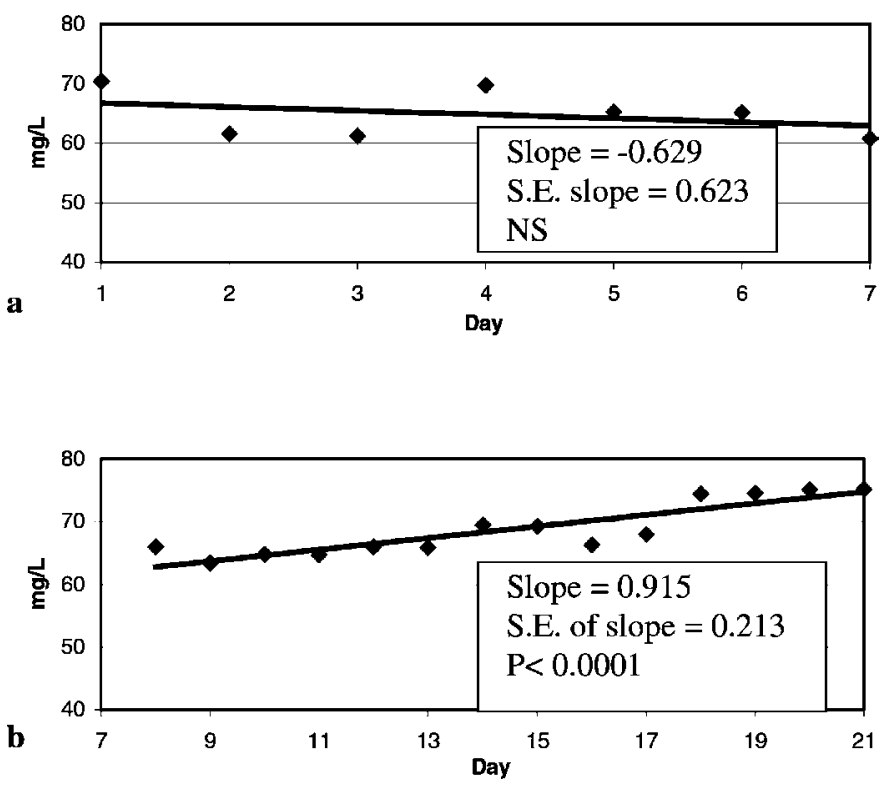

Figure 3. Allantoin concentration in milk over the course of experiment 3. a) Allantoin concentration before administration of bST (d 1 to 7), b) Allantoin concentration after administration of bST (d 8 to 21 ).
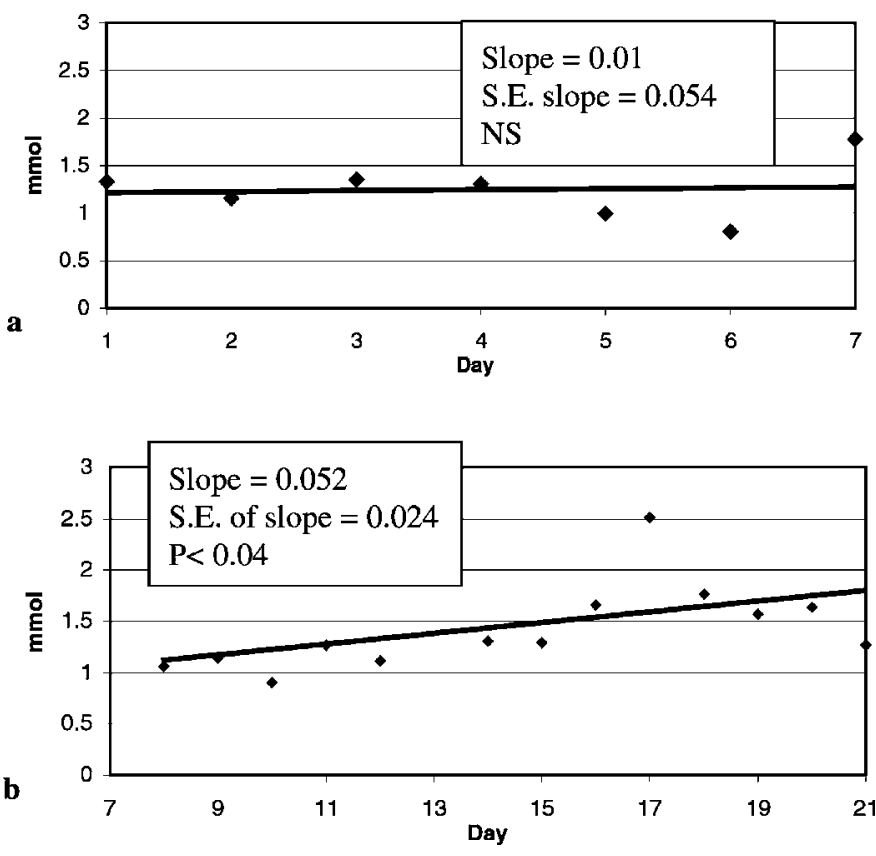

Figure 4. Amount of uric acid excreted per day over the course of experiment 3. a) Uric acid excretion before administration of bST (d 1 to 7), b) Uric acid excretion after administration of bST (d 8 to $21)$, c) Uric acid excretion for entire experimental period.

gland are assumed to be a result of plasma concentration and mammary blood flow (Shingfield and Offer, 1998). The increased milk yield would suggest increased blood flow and the possibility of an increased amount of allantoin transferred into the mammary gland vs. other possible excretion routes (renal and recycling via saliva) (Smith and McAllan 1970; Chen et al., 1990). This relationship was shown in a study by Shingfield and Offer (1998), in which the extent of variation in individual cow milk allantoin concentration was very similar to that of milk yield.

Uric acid secreted in milk is shown in Figure 4. There was no increase in uric acid concentration $(\mathrm{mg} / \mathrm{L})$ after bST administration. However, there was an increase $(P<0.04)$ in uric acid secretion $(\mathrm{mmol} / \mathrm{d})$ in milk after the administration of bST. This finding is due to increased milk yield. Uric acid concentration in milk is known to be more variable than allantoin in milk (Susmel et al., 1995, Timmermans et al., 2000). Giesecke et al. (1994) suggested the mammary gland itself contributes to the production of uric acid because the concentration of uric acid in milk exceeded that in plasma. Metabolism of uric acid into allantoin has not been demonstrated in the mammary gland. No uricase or uricase mRNA have been identified in extrahepatic rat tissues, including mammary gland (Motojima and Goto, 1990). Therefore, the increase in allantoin in milk would not be from uric acid catabolism in the mammary 
gland but suggested to be from passage of allantoin from plasma.

\section{Relationship Between Milk Yield and Allantoin Concentration}

The correlation coefficient between milk allantoin concentration and milk yield among the three experiments, ranged from 0.22 to 0.61 . Shingfield and Offer (1998) reported a strong correlation of 0.88 . However, in a more recent study by Timmermans (2000), milk yield did not significantly influence the allantoin concentration in the milk $\left(P<0.2 ; \mathrm{R}^{2}=0.005\right)$. In our study $\mathrm{R}^{2}$ values ranged from 0.05 to 0.37 .

\section{CONCLUSIONS}

Allantoin output ( $\mathrm{mmol} / \mathrm{d}$ ) increased with increased percentage of concentrate in the diet, while there was no difference in DMI (experiment 1). This change was detected by allantoin secretion in milk within $12 \mathrm{~h}$ (one milking) of the diet change. No difference in allantoin concentration was observed between a.m. and p.m. milkings. Milk samples for the purpose of allantoin determination can be obtained by various techniques without affecting allantoin concentration (experiment 2). Although DMI will remain constant, milk allantoin concentration is increased by bST administration within $14 \mathrm{~d}$ after administration. However, during the first $14 \mathrm{~d}$ following bST administration, estimates of microbial protein production derived from milk allantoin may be inaccurate due to increased milk production.

\section{REFERENCES}

Association of Official Analytical Chemists. 1990. Official Methods of Analysis. 15th ed. AOAC, Arlington, VA.

Bauman, D. E., P. J. Eppard, M. J. DeGeeter, and G. M. Lanza. 1985. Responses of high producing dairy cows to long-term treatment with pituitary somatotropin and recombinant somatotropin. J. Dairy Sci. 68:1352-1362.

Bauman, D. E. 1992. Bovine somatotropin: Review of an emerging animal technology. J. Dairy Sci. 75:3432-3451.

Chalupa, W., and D. T. Galligan. 1989. Nutritional implications of somatotropin for lactating cows. J. Dairy Sci. 72:2510-2524.

Chen, X. B. 1989. Excretion of purine derivatives by sheep and cattle and its use for the estimation of absorbed microbial protein. Ph.D. thesis. Univ. Aberdeen, Scotland.
Chen, X. B., and M. J. Gomes. 1992. Estimation of microbial protein supply to sheep and cattle based on urinary excretion of purine derivatives: An overview of technical details. Int. Feed Res. Unit, Occasional Publ. Rowett Research Institute, Aberdeen, United Kingdom.

Chen, X. B., F. D. DeB. Hovell, and E. R. Orskov. 1990. Excretion of purine derivatives by ruminants: Recycling of allantoin into the rumen via saliva and its fate in the gut. Br. J. Nutr. 63:197-205.

Etherton, T. D., and D. E. Bauman. 1998. Biology of somatotropin in growth and lactation of domestic animals. Physiol. Rev. 78:745-761.

Giesecke, D., L. Ehrentreich, and M. Stangassinger. 1994. Mammary and renal excretion of purine metabolites in relation to energy intake and milk yield in dairy cows. J. Dairy Sci. 77:2376-2381.

Goering, H. K., and P. J. Van Soest. 1970. Forage and fiber analyses. Agric. Handbook No. 379. Agric. Res. Serv., US Dep. Agric., Washington, DC.

Gonda, H. L., and J. E. Lindberg. 1997. Effect of diet on milk allantoin and its relationship with urinary allantoin in dairy cows. J. Dairy Sci. 80:364-373.

Motojima, K., and S. Goto. 1990. Characterization of liver-specific expression of rat uricase using monoclonal antibodies and cloned cDNAs. Biochim. Biophys. Acta 1087:316.

SAS User's Guide: Statistics, Version 8.0 Edition. 2001. SAS Inst., Inc., Cary, NC.

Shingfield, K. J., and N. W. Offer. 1998. Evaluation of milk allantoin excretion as an index of microbial protein supply in lactating dairy cows. J. Anim. Sci. 67:371-385.

Sibanda, S., J. H. Topps, E. Storm, and E. R. Orskov. 1982. The excretion of allantoin by ruminants in relation to protein entering the abomasum. Proc. Nutr. Soc. 41:75A.

Sigma Diagnostics. Procedure No. 684. Sigma Chemical Co., St. Louis, MO.

Smith, R. H., and A. B. McAllan. 1970. Nucleic acid metabolism in ruminants. Formation of microbial nucleic acids in the rumen in relation to the digestion of food nitrogen and the fate of dietary nucleic acids. Br. J. Nutr. 24:545-556.

Stangassinger, M., X. B. Chen, J. E. Lindberg, and D. Giesecke. 1995. Metabolism of purines in relation to microbial production. Pages 387-406 in W. V. Engelhardt, S. Leonhard-Marek, G. Breves and D. Giesecke, ed. Ferdinand Enke Verlag Ruminant Physiology: Digestion, Metabolism, Growth and Reproduction. Stuttgart, Germany.

Susmel, P., M. Spanguero, B. Stefanon, and C. R. Mills. 1995. Nitrogen balance and partitioning of some nitrogen catabolites in milk and urine of lactating cows. Livest. Prod. Sci. 44:209-219.

Tiermeyer, W., M. Stohrer, D. Giesecke. 1984. Metabolites of nucleic acids in bovine milk. J. Dairy Sci. 67:723-728.

Timmermans, S. J., L. M. Johnson, J. H. Harrison, and D. Davidson. 2000. Estimation of the flow of microbial nitrogen to the duodenum using milk uric acid or allantoin. J. Dairy Sci. 83:2387-2390.

Topps, J. H., and R. C. Elliott. 1965. Relationships between concentrations of ruminal nucleic acid and excretion of purine derivatives by sheep. Nature (Lond.) 205:498-499.

Valadares, R. F. D, G. A. Broderick, S. C. Valadares Filho, and M. K. Clayton. 1999. Effect of replacing alfalfa silage with high moisture corn on ruminal protein synthesis estimated from excretion of total purine derivatives. J. Dairy Sci. 82:2686-2696.

Wenham, G., 1979. Effects of cannulation on the intestinal motility. Ann. Rech. Vet. 10:157-159. 